\title{
水の微量分析法に關する研究(第2 報)
}

\section{過マンガン酸加里消損量の一新微量分量法に就て}

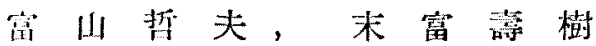

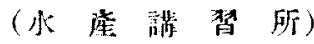 \\ 㽞和 12 年 7 月 27 日受理
}

水中に住在して唇る物資口内有機物は特江微生物によつて分解された場合に水中の酸素之絬

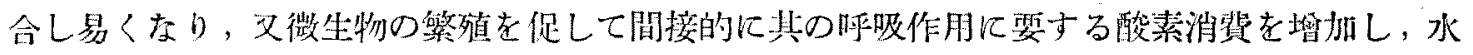

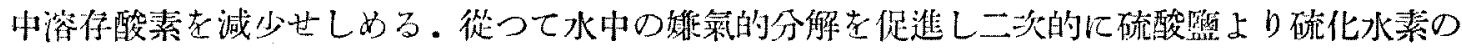

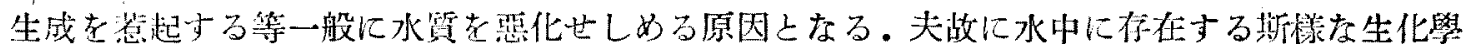

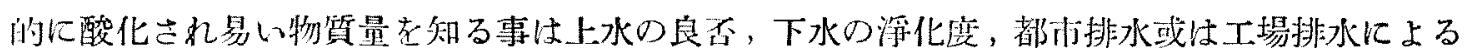

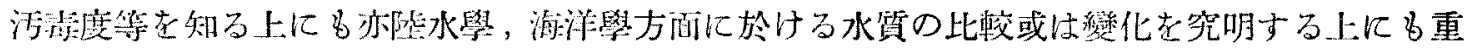
淛な事項である。此の凌化され易い物筫の量考知るには現在二つの方法があり其の一は Bio-

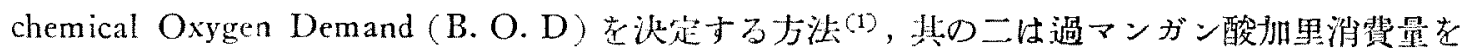

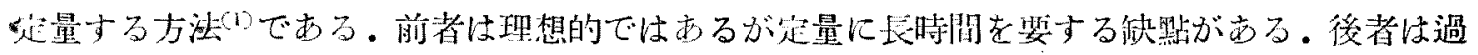
マンガン酸加里を以て還元性物筫を酸化し其の際分解した過マンガン酸加里の量或はそれに相

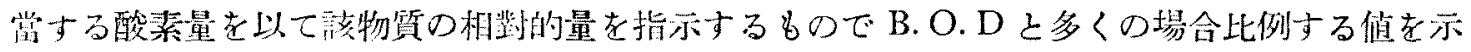

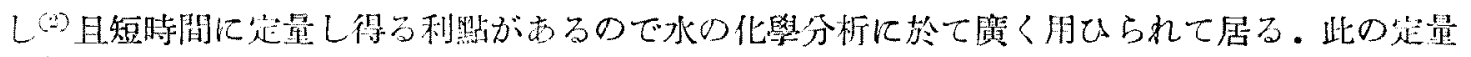
法に数種の變法があり又各國に位つて種々の變法が堔用されて居るがは，一般に上水の分析に

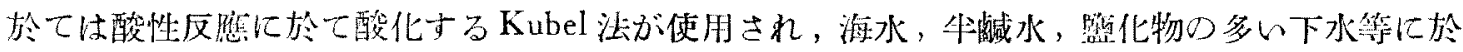
てはアルカリ性反應に於て酸化するSchulze 法が探用されて居る。

著者等は過マンガン酸加里消监量の公量法在少量の供試水にて行ひ操作克简易化すると同時

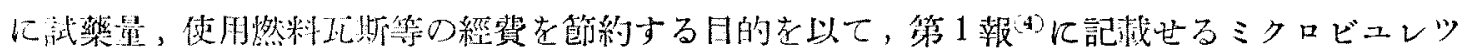
卜立使用しSchulze 法の微量化を企圖して先づ其定量條件を暞ぬ吟味せるに，該法に二つの誤

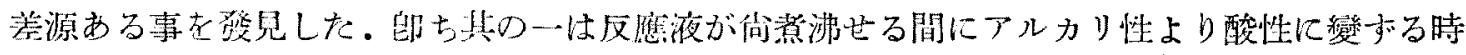

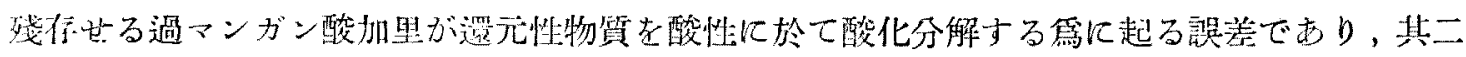

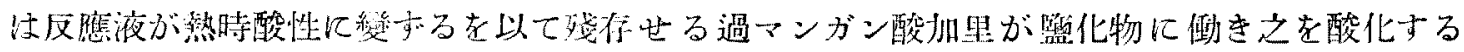
Side reactionに原因する榄差であって之等の關係は炏式にて示す事が出柬る。

$$
\begin{aligned}
& \triangle E=k\left(P_{S}-J^{\prime}\right)+k^{\prime}\left[\mathrm{Cl}^{\prime}\right] \\
& \angle E=\text { Schulze 法の䜅差 } \\
& P_{s}=\text { 酸性に於ける過マンガン酸办里渻瞔量 } \\
& P_{B}=\text { アルカリ性に於ける過マンガン酸加里消䀺量 } \\
& k \text { 及び } k^{\prime} \text { は比例恒數 }
\end{aligned}
$$




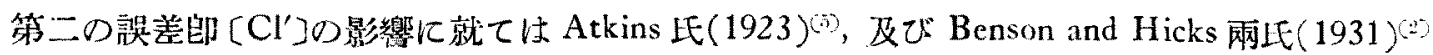

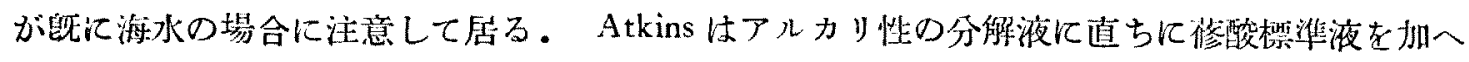
る如く改良して居るがフルカリ性に於ては $\mathrm{KMnO}_{4}$ 上葆酸との反應が暹い事，酸性に變ずる 時徐々に酸を加ふべき事及び逆㵜定の條件を一定にすべを事等の缺然老認めて居る。此の外該

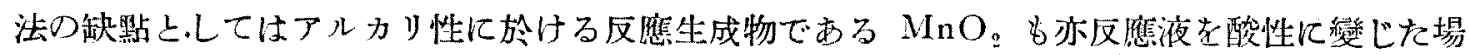

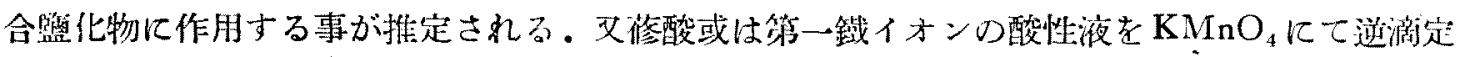

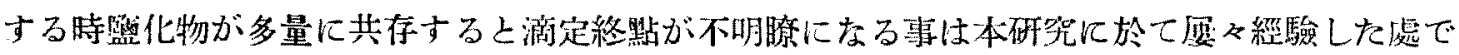

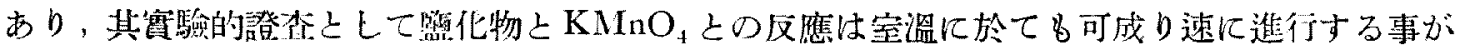

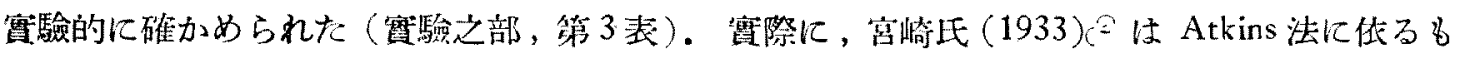

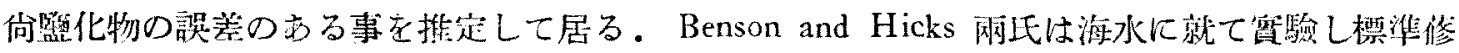

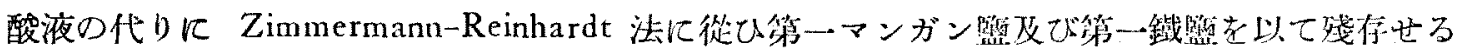

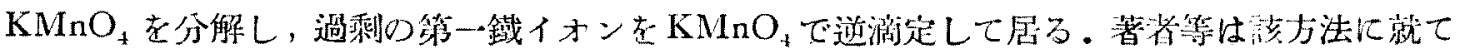

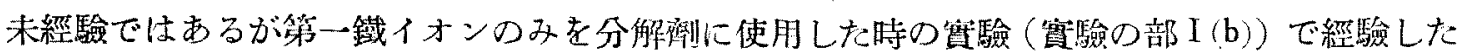

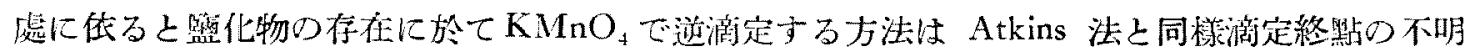
膫な缺黙があると認める。

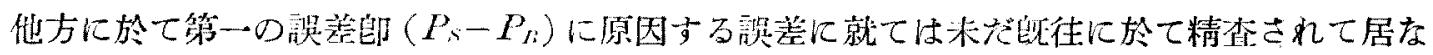

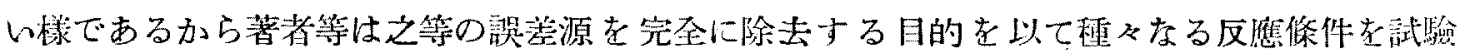

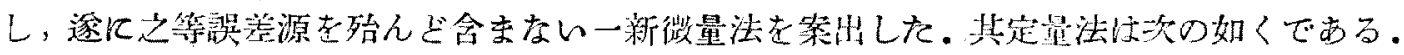

\section{新徽量定量法並に定量に要する試薬及び器具}

\section{1. 定 量 法}

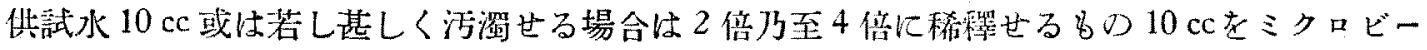

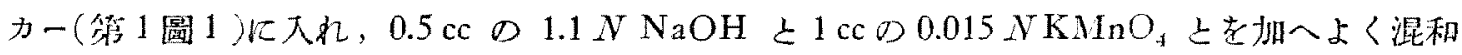

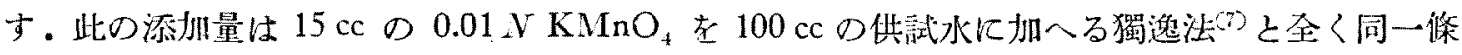

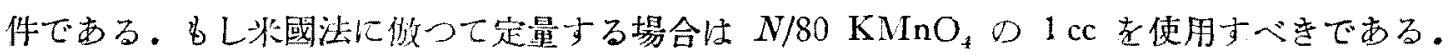

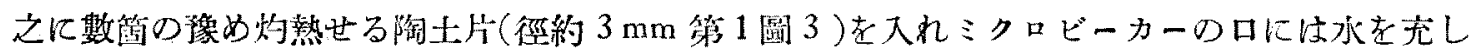

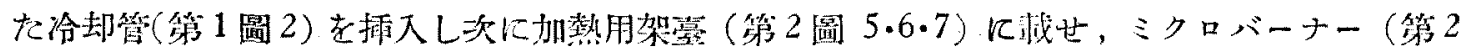

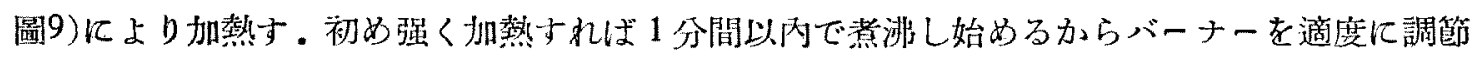

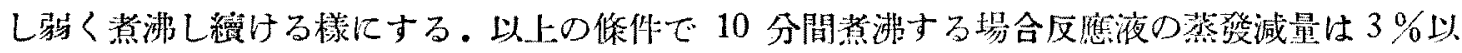

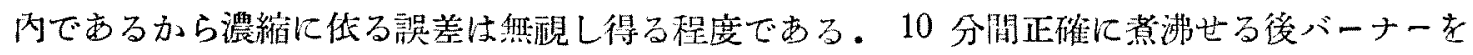
去り冷却管孝除いて 5 滴の $10 \% \mathrm{KI}$ 液老扣人殘存する $\mathrm{KMnO}_{4}$ 考分解し，次にミクロビ一 カー老水に浸して內容液を冷却する。反應液が全く冷却すれば $0.2 \mathrm{cc} \mathrm{H} \mathrm{H}_{2} \mathrm{SO}_{4}(1: 3)$ 孝扣一遊

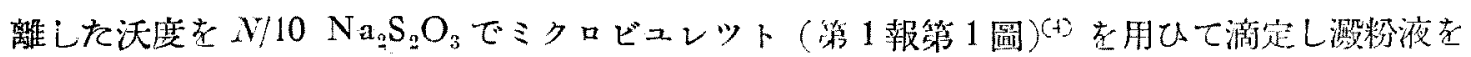

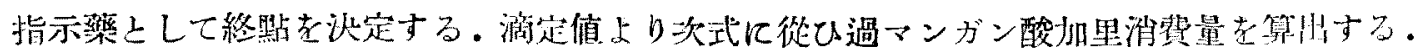




$$
\begin{aligned}
& P=(B-T) \times \frac{1}{K} \times \frac{100}{S^{\prime}} \\
& P^{\prime}=P \times 3.16 \\
& P^{\prime \prime}=P \times 0.80
\end{aligned}
$$

$P=$ 過マンガン酸加里消費量 (cc $N / 100 \mathrm{KMnO}_{4} / 100 \mathrm{cc}$ Sample)

$P^{\prime}=\quad " \quad\left(\mathrm{mg} \mathrm{KMnO}_{4} / 1000 \mathrm{cc}\right.$ Sample)

$P^{\prime \prime}=\quad " \quad(\mathrm{mg} \mathrm{O} / 1000 \mathrm{cc}$ Sample)

$B=$ 盲驗に於ける $N / 10 \quad \mathrm{Na}_{2} \mathrm{~S}_{2} \mathrm{O}_{3}$ の滴定量をミクロビュレツトの目盛にて示せる數 $T^{\prime}$ =主筫驗に於ける $N / 10 \quad \mathrm{Na}_{2} \mathrm{~S}_{2} \mathrm{O}_{3}$ の滴定量をミクロビニレツトの目篮にて示せる數 $R=$ 力價の決定に於て槽準液 $N / 100 \mathrm{KHI}_{2} \mathrm{O}_{6}$ の $1 \mathrm{cc}$ 亿對して要した $\mathrm{N} / 10 \mathrm{Na} \mathrm{N}_{2} \mathrm{~S}_{2} \mathrm{O}_{3}$ の量をミクロビュレツトの目盛にて示せる數

$S=$ 定量に用ひた供試水 $\mathrm{cc}$

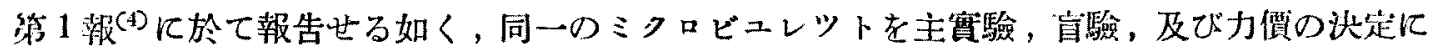
使用すれば，ミクロビユレットの 1 目盛の容辕及び $\mathrm{Na}_{2} \mathrm{~S}_{2} \mathrm{O}_{3}$ 液のFactor 老特別に讨定する

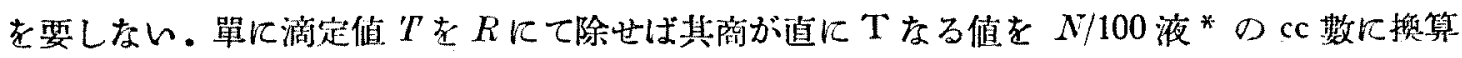
した值となる。

\section{2. 定量に使用する試藥}

（1）標準 $N / 100$ 重沃素酸扣里： $0.3250 \mathrm{~g} . \mathrm{KHI}_{2} \mathrm{O}_{6}$ (Kahlbaum 分析用）老水江溶し精 密に 1 L 几充す。

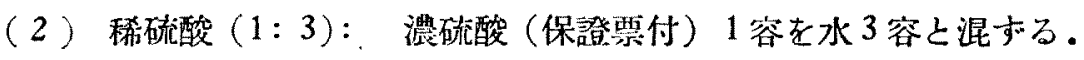

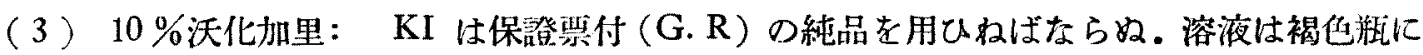
實へる。

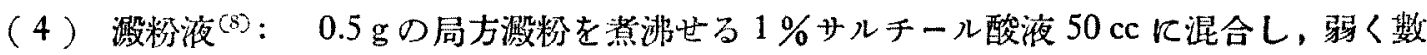
分間者沸して搌粉を溶解し水を以つて約 $500 \mathrm{cc}$ に稀敉士。此液は感度も上く且長時間の保存 に堪へる。

（5） $1 / 10 \mathrm{~N}$ チオ硫酸ソーダ： $25 \mathrm{~g} \mathrm{Na}_{2} \mathrm{~S}_{2} \mathrm{O}_{3}$ を水に溶解し $1 \mathrm{~L}$ 亿充し約 $0.5 \mathrm{~g}$ の哭水 $\mathrm{Na}_{2} \mathrm{CO}_{3}$ 老加へて保存す．此液恃次の如くして力價を決定する。

$0.2 \mathrm{cc} 10 \% \mathrm{KI}$ に約 $5 \mathrm{cc}$ の水を加へ次に $\mathrm{H}_{2} \mathrm{SO}_{4}(1: 3)$ (1: $0.2 \mathrm{cc}$ 老加へた混合液に精密に $1 \mathrm{cc}$ の柴準 $\mathrm{KHI}_{2} \mathrm{O}_{6}$ を加へ混和して遊離した沃展を $1 / 10 \mathrm{~N} \mathrm{Na} \mathrm{N}_{2} \mathrm{~S}_{2} \mathrm{O}_{3}$ にてミクロビユレッ

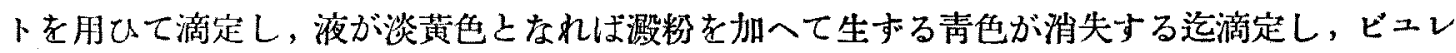
ットの目盛 $(R)$ を讀む．此の力價の決定は異なるビュレットを用ふる場合には其の都度行ふこ きである†。

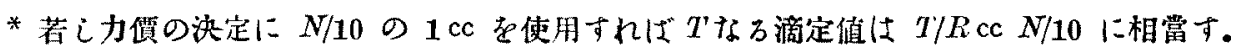

†ビユレットの一目盛が精密に 1/1000 cc に目盛つたもののに於ては 100/R が $N / 10 \mathrm{Na}_{2} \mathrm{~S}_{2} \mathrm{O}_{3}$ の力價で

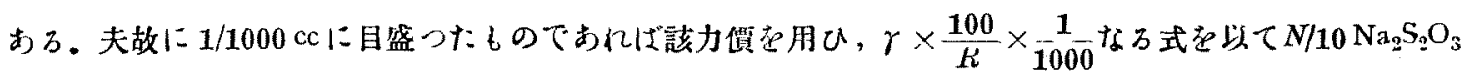
の cc 数に換算す 万事が出來万。但 $i r=$ 賽驗值 $(1 / 1000 \mathrm{cc}$ 單值 $)$ 


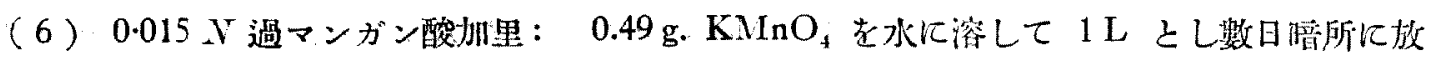

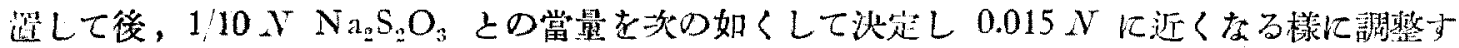
る.節 $0.2 \mathrm{cc} 10 \% \mathrm{KI}$ 在的 $5 \mathrm{cc}$ の水にて稀釋し, そに $0.2 \mathrm{cc}$ の $\mathrm{H}_{2} \mathrm{SO}_{4}(1: 3)$ t加へた混

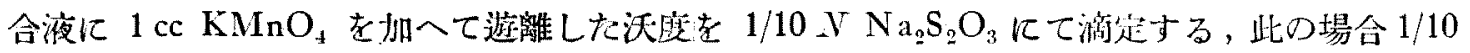

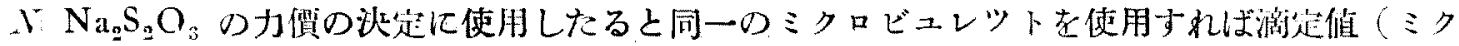

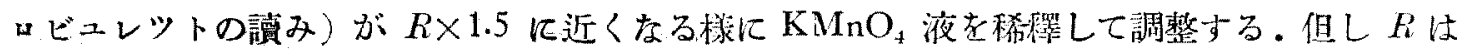

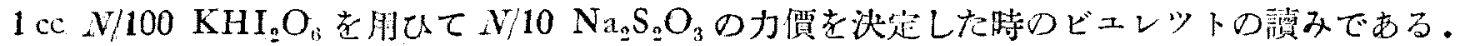

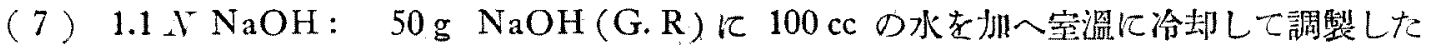
$33 \%$ (重量) $\mathrm{NaOH}$ 溶液の $10 \mathrm{cc}$ 在 $100 \mathrm{cc}$ に稀龂子る。

\section{3. 定量に使用する器具}

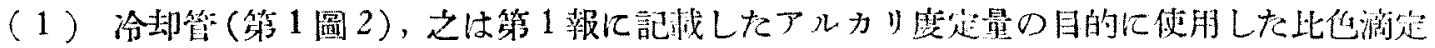
察ですつてこの目的に乘用する。

(2) 內容約 $30 \mathrm{cc}$ のミロビーカー（第 1 圖 1)

(3) $1 \mathrm{cc}$ 及び $10 \mathrm{cc}$ ホールピペツト

(4) $0.5 \mathrm{ec}$ ゴム棺付メスピペツト 3 本

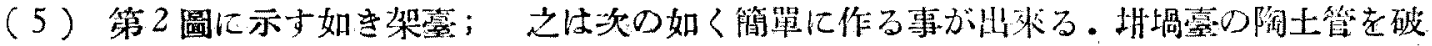

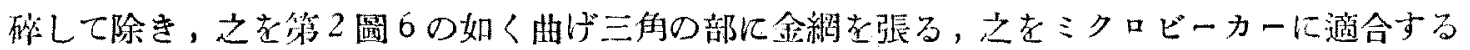

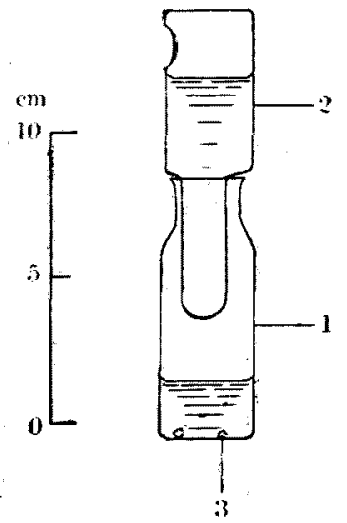

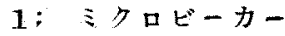

2：冾 却管

3: 陶 $\pm \boldsymbol{h}^{2}$

第 1 圖

$\mathrm{KMnO}_{4}$ 消费量定星 用容器

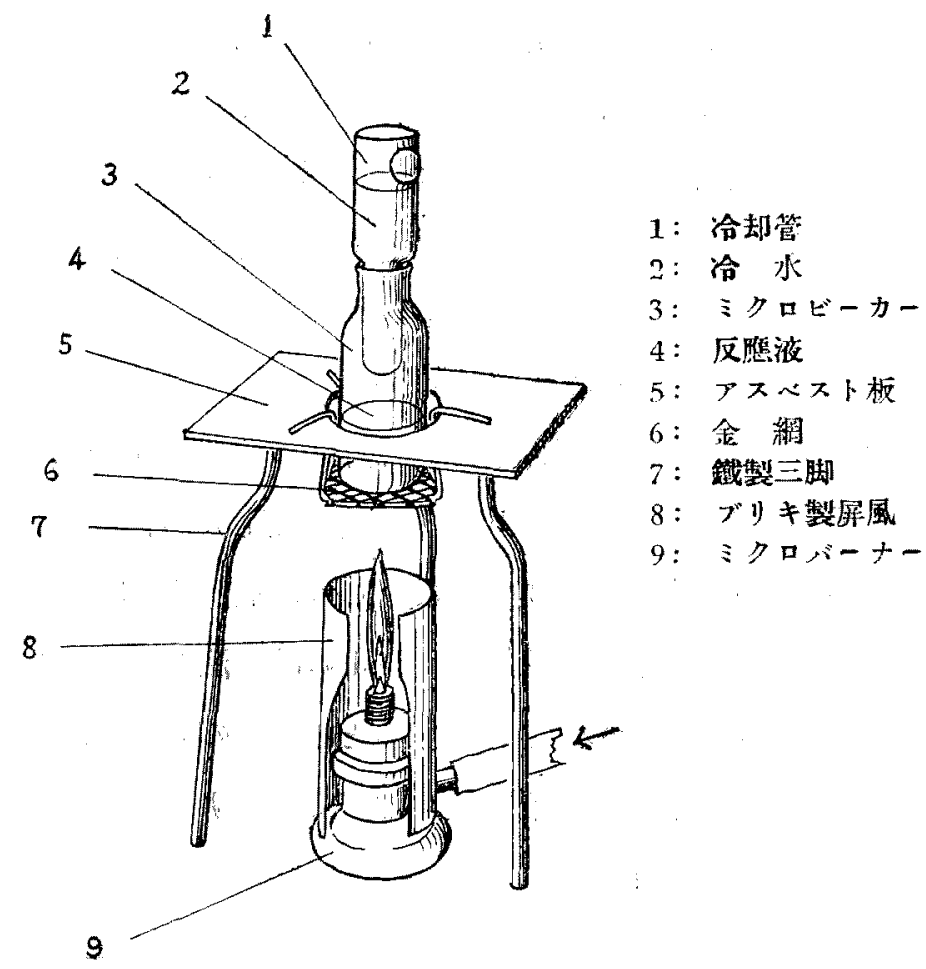

第2 圖 $\mathrm{KMnO}_{4}$ 消費量定量用装犆 


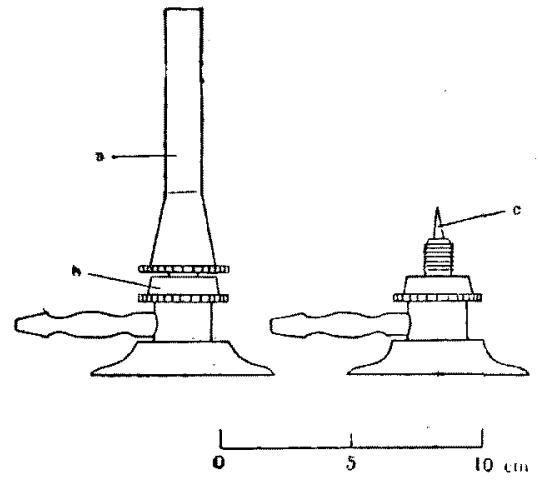

第 3 圖 ミクロバーナーの構成

大さの穴をあけたアスベスト板（第2 圖 5)飞裝置

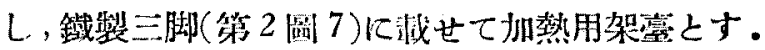
（6）ミクロバーナー： 之は島津式ブンゼン 燈の上部（a)(第 3 滈)を取り去つて（b)部のみ上 し其の心棒 (c)の圍りょり隕出するガスに點火し ミクロバーナーに使用する事が出來る。何之に對 し風老避けるため第 2 圆 (8)の如き圆衙の衙立て を用意するのが便である。

\section{菑 驗之 部}

\section{Schulze 法に於ける誤差源の吟味}

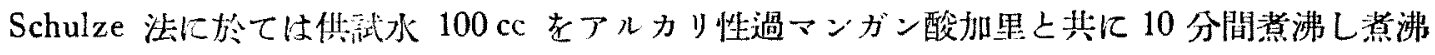

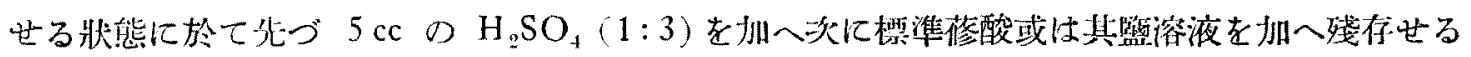

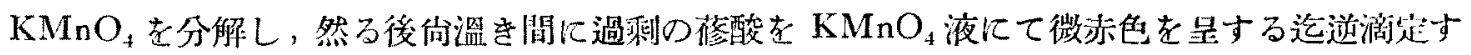
万。此操作江於て硫酸を加へて反應液を酸性几變ずる場合向反應液は㥿沸して居るので短時間 ではをるが酸性に於ける分解の進行する事が推察される。此酸性に於ける酸化を受ける物質に は主として有機物及び監化物が䓅へられる.夫故に反應液を豫め冷却して後硫酸を加へる樣に 操作を改變して假に之を“冷却洼”と呼び上記の原因に上る誤差の吟味を行つた。

(a) 酸性に於ける有機物酸化几原因する誤现

此の誤巻の怜味のために Schulze 法を沃の如く改變した。毁 $5 \mathrm{cc}$ の供試水に $0.5 \mathrm{cc} 2.2 \%$

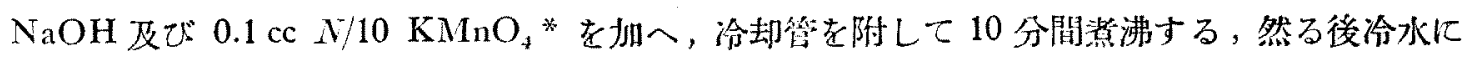
浸して內容老冷却し，次に $0.2 \mathrm{cc} \mathrm{H}_{2} \mathrm{SO}_{4}(1: 3)$ 老加一更に標準 $N / 100$ Eerrous Ammonium

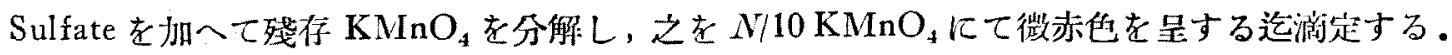
又 Schulze 氏原法も上記變法之同一條件にする疍 $5 \mathrm{cc}$ の供試水に $0.5 \mathrm{cc} 2.2 \% \mathrm{NaOH}$ 及び $0.1 \mathrm{cc} \mathrm{N} / 10 \mathrm{KMnO}_{4}$ t加へ 10 分間热沸分解したる後之に $0.2 \mathrm{cc} \mathrm{H}_{2} \mathrm{SO}_{4}(1: 3)$ を加一成るご く速に $1 \mathrm{cc} の N / 100$ Oxalic acid を加人, 加熱豪より去つて溫時之を $N / 10 \mathrm{KMnO}_{4}$ を以て

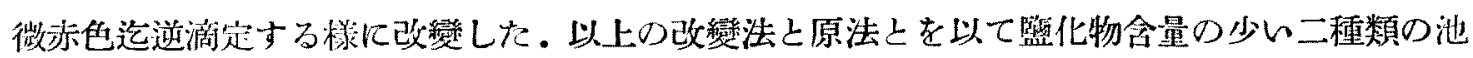
水に就て定量した夫《の值を比較すると第 1 表の如くであり，常に原法の場合が結果大となり

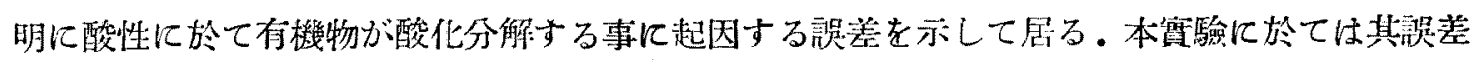
は約 10〜30\%に澺した。

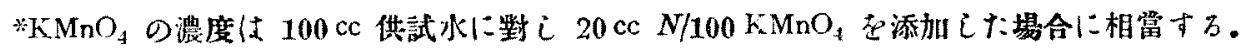


第 1 表 酸性に於て起る有機物酸化に原因与る瀷差

\begin{tabular}{|c|c|c|c|c|c|c|c|c|}
\hline 供試 & \multicolumn{4}{|c|}{ I } & \multicolumn{4}{|c|}{ II } \\
\hline 少 法 & 主賏驗 & 它 & 驗 & $\begin{array}{l}\mathrm{KMnO}_{4} \\
\text { 消費量 }\end{array}$ & 主惯驗 & 盲 & 驗 & $\begin{array}{l}\mathrm{KMnO}_{4} \\
\text { 消蛽量 }\end{array}$ \\
\hline 原 法 & $\begin{array}{l}8.30 \\
8.10 \\
8.10 \\
7.90\end{array}$ & & $\begin{array}{l}0.83 \\
0.62\end{array}$ & 7.40 & $\begin{array}{l}11.70 \\
11.60 \\
11.90\end{array}$ & & $\begin{array}{l}0.94 \\
1.04 \\
1.04 \\
0.83\end{array}$ & 10.75 \\
\hline 冷却法 & $\begin{array}{l}7.10 \dagger \\
7.10^{\prime \prime} \\
6.90 \$ \\
7.10^{\prime \prime}\end{array}$ & & $\begin{array}{l}0.42 \\
0.62\end{array}$ & 6.60 & $\begin{array}{l}8.95 \\
9.20 \\
8.95\end{array}$ & & $\begin{array}{l}0.62 \\
0.73 \\
0.52 \\
0.62\end{array}$ & 8.35 \\
\hline
\end{tabular}

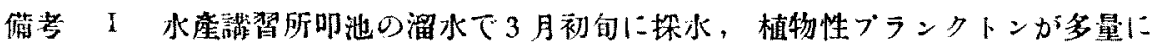
繁殖して呂け。

II 同上但し 4 月下的に採水したものである。

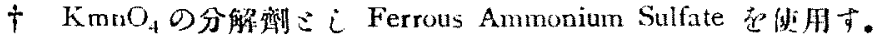

$\$ \quad " \quad \mathrm{H}_{2} \mathrm{O}_{2}$

(b) 酸性に於て監化物を酸化する事に原因する誤虚

酸性に於て $\mathrm{KMnO}_{4}$ は然化物に作用し㐸の反應式に從し $\mathrm{Cl}^{\prime}$ 酸化して $\mathrm{Cl}_{2}$ にる事は 一般に知られて居る。

$$
10 \mathrm{NaCl}+2 \mathrm{KMnO}_{4}+8 \mathrm{H}_{2} \mathrm{SO}_{4} \rightleftarrows 5 \mathrm{Cl}_{2}+2 \mathrm{MnSO}_{4}+\mathrm{K}_{2} \mathrm{SO}_{4}+5 \mathrm{Na}_{2} \mathrm{SO}_{4}+8 \mathrm{H}_{2} \mathrm{O}
$$

過マンガン酸加里消費量定量の場合此 Side reaction を避けるため Schulze 法に於てはアル カリ性に於て分解して虍るが，加熱分解後意沸時に硫酸を加入酸性としたる場合短時間ではあ るが以上の反應が起ると考へられる。此點を哈味するため供試水 $5 \mathrm{cc}$ に $0.4 \mathrm{cc} の \mathrm{NaCl}$ 铇和

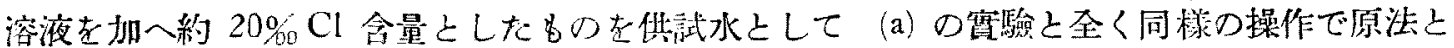
椧却法とによつて这照し第2表り如き絬果索得た。

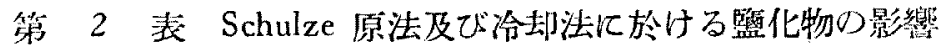

\begin{tabular}{|c|c|c|c|c|c|c|c|c|}
\hline & 圭 & 䁈 & 驗 & 盲 & & & 驗 & \multirow{2}{*}{ 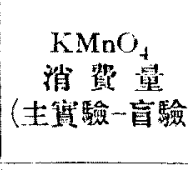 } \\
\hline & $\begin{array}{l}\mathrm{KMnO}_{4} \\
\text { 方時間 } \\
3-5 \text { 秒 }\end{array}$ & $\begin{array}{l}\text { 酸性に } \\
\text { 10秒 }\end{array}$ & $\begin{array}{l}\text { 厂作用 } \\
30 \text { 秒 }\end{array}$ & \multicolumn{4}{|c|}{$\begin{array}{l}\mathrm{KMnO}_{4} \text { 加酸性に於七作朋 } \\
\text { する時䦓 }\end{array}$} & \\
\hline $\begin{array}{l}+\mathrm{NaCl} \\
\text { 原法 }\end{array}$ & $\begin{array}{l}12.5 \\
12.4 \\
12.7 \\
12.3\end{array}$ & . & & $\begin{array}{l}1.35 \\
1.25 \\
1.56\end{array}$ & $\begin{array}{l}1.98 \\
2.08\end{array}$ & $\begin{array}{l}4.80 \\
4.16\end{array}$ & $\begin{array}{l}5.84 \\
5.30\end{array}$ & 11.10 \\
\hline$-\mathrm{NaCl}$ & $\begin{array}{l}11.7 \\
11.6 \\
11.9\end{array}$ & · & & $\begin{array}{l}0.83 \\
1.04 \\
0.95 \\
1.04\end{array}$ & & & $\begin{array}{l}1.25 \\
1.35\end{array}$ & 10.80 \\
\hline
\end{tabular}




\begin{tabular}{c|cc|cc|c} 
& & & & \\
& $\mathrm{NaCl}$ & 10.4 & 1.87 & 2.80 & 8.60 \\
& 10.6 & & 1.87 & 2.70 & \\
冾却法 & 10.4 & & & \\
$-\mathrm{NaCl}$ & & & & \\
& 9.95 & 9.40 & 0.60 & 0.94 & \\
& 8.85 & 9.10 & 0.73 & 0.94 & 8.34 \\
\hline
\end{tabular}

储考

定量佟件(原法)：[供試水 $5 \mathrm{cc} \pm 0.4 \mathrm{cc}$ 能和 $\mathrm{NaCl}+0.5 \mathrm{cc} 2.2 \% \mathrm{NaOH}+0.1 \mathrm{cc} N / 10 \mathrm{KMnO}$ ]

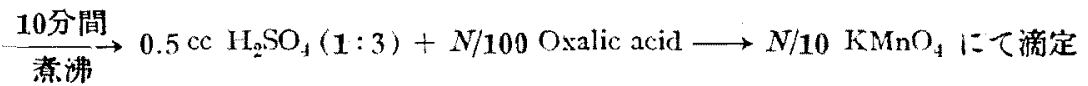
(冷却法)：〔同上

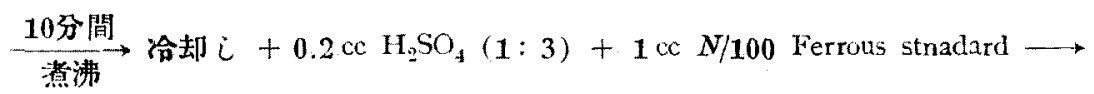
$\mathrm{N} / 10 \mathrm{KMnO}_{4}$ にて湳定.

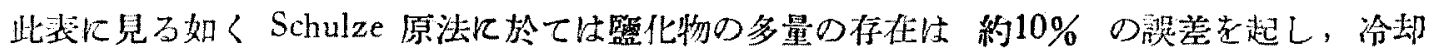

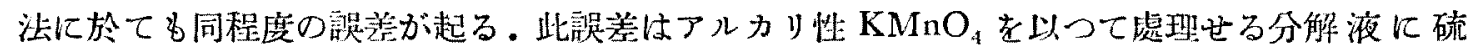

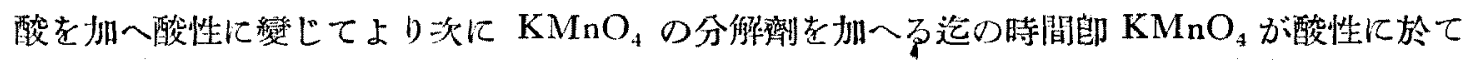
作用する時間の長短により甚しく變化する゙，即第2 表目驗の項に示せる如く潦沸狀態に於て酸

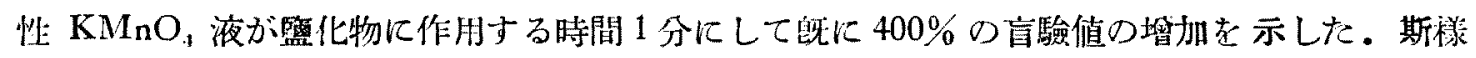

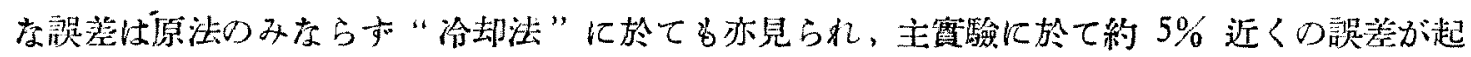
り，首驗值に於ては 1分間の作用時間に於て約 50\%の增加を示した。之はアルカリ性 $\mathrm{KMnO}_{4}$ の分解物である $\mathrm{MnO}_{2}$ が酸性の第一鐵イオンにより徐々に分解される第，其間既に監化物に

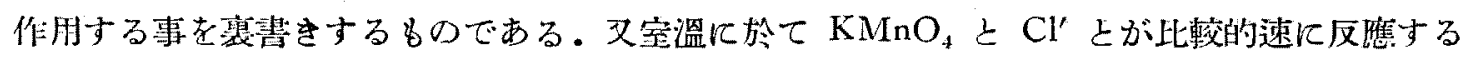
事賽は第 3 表に示した望驗結果に見るる明かである。この室溫に於ける酸化作用は叉 $\mathrm{KMnO}_{4}$ で逆滴定し微赤色に至らしめる時にも進行するもので盤化物の多い場合は終點の微赤色は數秒 にして消失し終點を不明暸にし滴定値の過大老來す事を認めた。

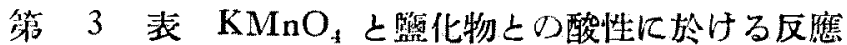

\begin{tabular}{|c|c|c|c|}
\hline 蒸溜水 & 師 & 5 分間放置 & 10分間放置 \\
\hline \multirow{4}{*}{$+\mathrm{NaCl}$} & 0.73 & 1.04 & 1.25 \\
\hline & 0.83 & 1.04 & 1.25 \\
\hline & 0.83 & 1.14 & 1.35 \\
\hline & 0.73 & 1.14 & \\
\hline \multirow{2}{*}{$-\mathrm{NaCl}$} & 0.10 & \multirow{2}{*}{$-\infty$} & 0.20 \\
\hline & 0.10 & & 0.20 \\
\hline
\end{tabular}


借考

定量條件: [5 $\mathrm{cc}$ 䕩溜水 $\pm 0.4 \mathrm{cc}$ 敘和 $\left.\mathrm{NaCl}+0.5 \mathrm{cc} 2.2 \% \mathrm{NaOL}+0.1 \mathrm{cc} \mathrm{N} / 10 \mathrm{KMnO}_{4}\right]+0.2 \mathrm{cc}$

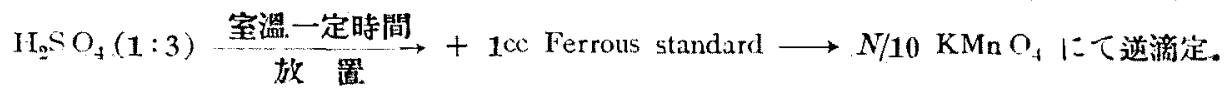

\section{II 新微量法の吟味と原法との比較}

以上の惯驗に上つて Schulze 法に於ては分解後反焤液をアルカリ性より酸性に變化する篇 に哭差が起る事が明かとなつた。又分解液を酸性に變する前に先づ泠却して $\mathrm{KMnO}_{4}$ が酸性: に於て反應する速度を減する粎に改良するも向完全でない事支知つた．夫故に速かに殘存 $\mathrm{KMnO}_{+}$老分解する方法として沃化加里を加へて殘存 $\mathrm{KMnO}_{+}$在 Iodometric 几測定する方

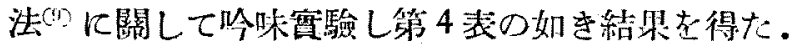

\section{第 4 翌 沃度啮の定量佟件の吟味}

\begin{tabular}{|c|c|c|c|c|c|}
\hline \multirow{2}{*}{ 供陚水 } & \multirow{2}{*}[\mathrm{A}]{} & \multirow{2}{*}{ [B] } & \multicolumn{3}{|c|}{$[\mathrm{C}]$} \\
\hline & & & 師時 & 30 秒 & 60 秒 \\
\hline 盬化物含量 & 3.80 & 3.85 & 3.95 & 4.30 & 4.85 \\
\hline & 3.70 & $3: 80$ & 3.90 & 4.35 & 4.75 \\
\hline の少い池水 & 3.80 & 3.75 & & 4.25 & \\
\hline
\end{tabular}

䚚考

定星條件 : 10cc Sample + 0.5ce $1.1 \mathrm{~N} \mathrm{NaOIT}+1 \mathrm{cc} N / 100 \mathrm{KMnO}_{4}$

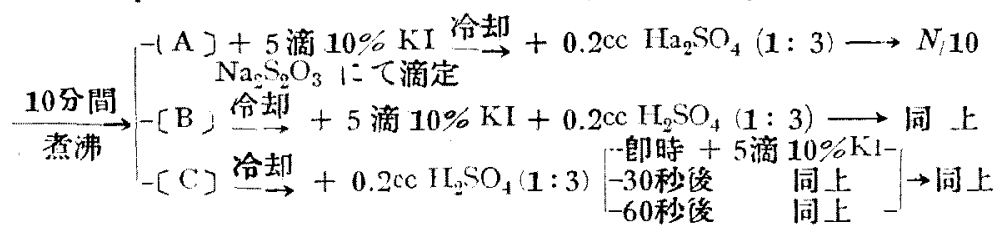

之に依る上沃度法に於ても豫め酸性にして次に沃化加里を加へる操作に於ては明に多少の誤 差を生じ，しかも其誤差は酸性にしてより沃化加里在加一る迄の時間の長短に比例して居る。

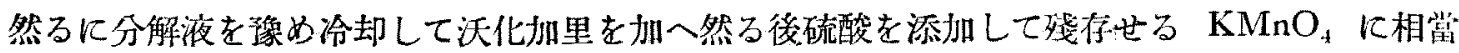
する沃度を遊離して之を $\mathrm{Na}_{2} \mathrm{~S}_{2} \mathrm{O}_{3}$ にて䇏定定量せる值は，分解液を酸性として次に能ふ限り 速て沃化加里を加へて $\mathrm{KMnO}_{4}$ を分解し生成した沃度を定量した值と殆ど同一結果であつた 郎ち 10 分間了ルカリ性 $\mathrm{KMnO}_{4}$ で有機物圭分解した後残存して居る $\mathrm{KMnO}_{4}$ 考分解するに はアルカリ性の液に KI を加ふれば方分である事在知つた。文此場合热沸せる分解液に直ち に沃化加里を加へを場合も，者沸せる分解液を豫的冷却して後沃化加里を加へた場合を全く同 一結果を與へたので，10 分間分解した者沸溶液に直ちに沃化加里を加へ然る後室溫迄椧却し

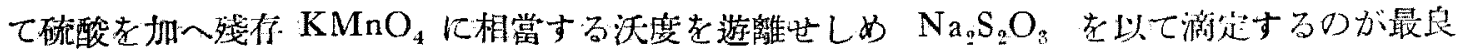
法である事が碓められた。 


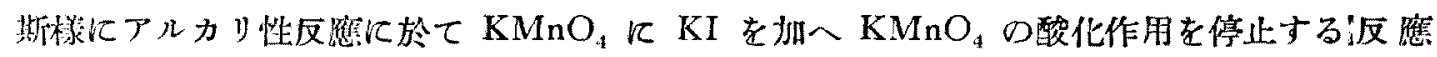
は恐らく（1）式に示す如き高次化合物或は其類似反應物が生成する事に依ると推定される. 何となれば $\mathrm{KMnO}_{4}$ のアルカリ性溶液に $\mathrm{KI}$ 老加へると沃度を遊離する事なく且溶液は直ち

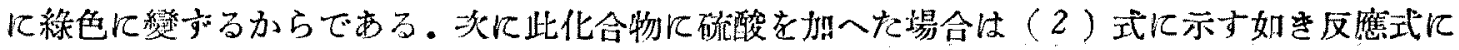
從ひ $\mathrm{KMnO}_{4}$ 亿虽量の沃度を遊離するもの上考へられる。

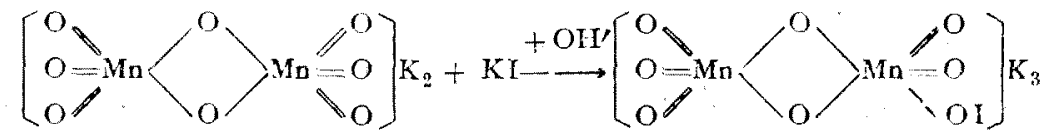

7 儒の $\mathrm{Mn}$

6 䍀の $\mathrm{Mn}$
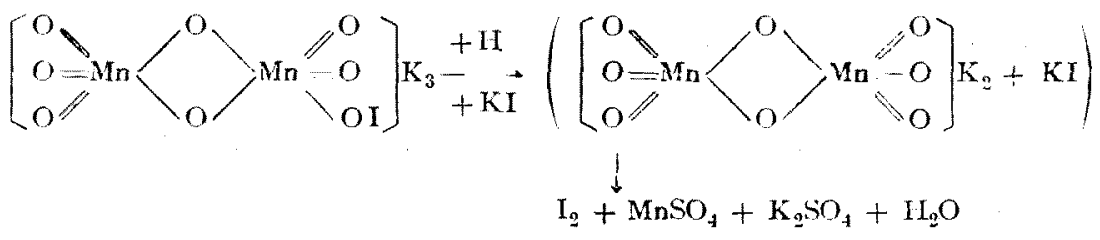

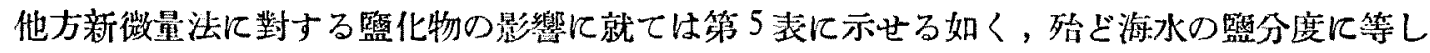
々 $20 \mathrm{~g} / L$ の醴素イオンの存在は約 $5 \%$ 以下の誤差老生するるに留り，從つて通常の下水或は處 理せる下水に含まる〉程度の照化物に起因する誤美は僅少と見做して差支へない。

\section{第 5 表 新微量法に於ける $\mathrm{NaCl}$ の誤菜}

\begin{tabular}{|c|c|c|c|c|c|}
\hline & & 圭 & 驗 & 盲 & 驗 \\
\hline \multirow{4}{*}{\multicolumn{2}{|c|}{$+\mathrm{NaCl}$}} & \multicolumn{2}{|c|}{ ウインクラー單位 } & \multicolumn{2}{|c|}{ ウインクラー單位 } \\
\hline & & \multicolumn{2}{|r|}{5.10} & \multicolumn{2}{|c|}{0.60} \\
\hline & & \multicolumn{2}{|r|}{5.10} & \multicolumn{2}{|c|}{0.60} \\
\hline & & \multicolumn{2}{|r|}{5.05} & \multicolumn{2}{|c|}{0.65} \\
\hline \multirow{3}{*}{\multicolumn{2}{|c|}{$-\mathrm{NaCl}$}} & \multicolumn{2}{|r|}{4.85} & \multicolumn{2}{|c|}{0.30} \\
\hline & & \multicolumn{2}{|r|}{4.80} & \multicolumn{2}{|c|}{0.30} \\
\hline & & \multicolumn{2}{|r|}{4.75} & \multicolumn{2}{|c|}{0.35} \\
\hline
\end{tabular}

倫考

定量條件: $10 \mathrm{cc}$ Sample $\pm 0.8 \mathrm{cc}$ 能和 $\mathrm{NaCl}+0.5 \mathrm{cc} 1.1 \mathrm{~N} \mathrm{NaOH}+1 \mathrm{cc} \mathrm{N} / 100 \mathrm{~K} \mathrm{MnO}_{4}$

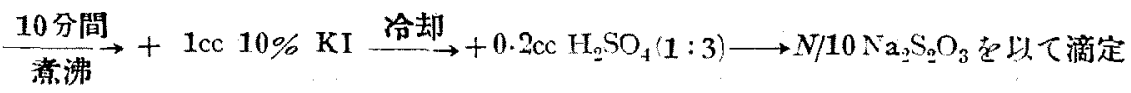

少第 5 表に於て $\mathrm{NaCl}$ 浱加の場合の盲驗量が大である事は $\mathrm{NaCl}$ として國圼の化學用純の

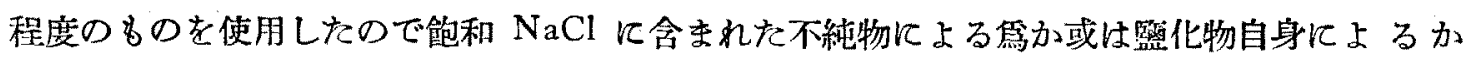
は不朋である。

序上の如き系統的吟味の結果茲に著者等の探用したす法は前記定量法の項に記截せる如くで ある。本定量法を以て同一供試水に就を 8 回定量を行ひ方法の正確度を檢したるに第 6 表の如 き絬果で嫩準偏差士 $1.1 \%$ を示した。 
第 6 琵 新微量法の精密度

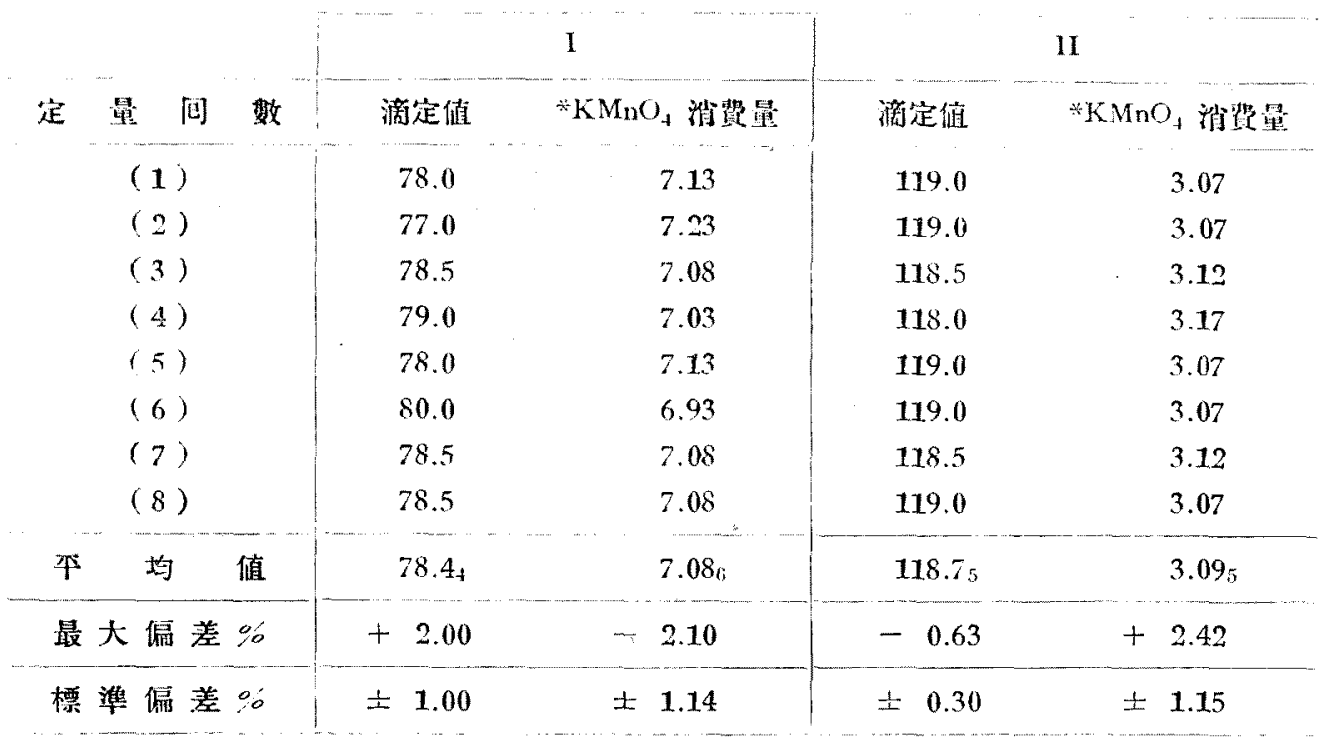

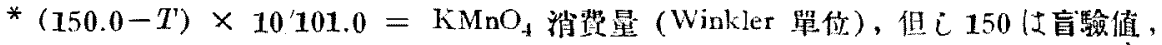

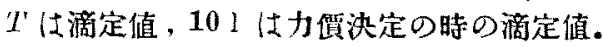

份此場合 $\mathrm{KMnO}_{4}$ 消費量 7 なる供武水の場合壮 3 なる供苚水の場合に比し滴定储の偏差が遥 机大であつた，之现らく $\mathrm{KMnO}_{4}$ 之有機物之の反應次數が相互の量的關係化上り支配吉れ 有機物多量の時は二次反應老当俳ふ雼 $\mathrm{KMnO}_{4}$ 分解量を不均一ならしめるものと推定される が此點は今後の研究により阙明したい，次に改良法並に Schulze 原法に依て監化物を多量に 合む溜水及で隅田川河口の水を分析した結果㤌第7表に示せる如くで，Schulze 啮壮裳に過大

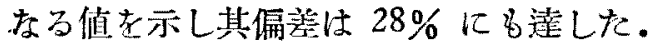

第 7 表 新微量法已 Schulze 原法々の比校

\begin{tabular}{|c|c|c|c|c|c|c|}
\hline \multirow{2}{*}{ 供試 水 } & \multicolumn{3}{|c|}{ I } & \multicolumn{3}{|c|}{$1 \mathrm{I}$} \\
\hline & 定量值 & 平均值 & 平均誤差\% & 定星值 & 平均值 & 平均誤差 0 \\
\hline \multirow[b]{2}{*}{ 涹微 } & \multicolumn{3}{|c|}{ ウインクラー單位 * } & \multicolumn{3}{|c|}{ ウインタラー單位 * } \\
\hline & $\left.\begin{array}{l}4.85 \\
4.80 \\
4.75 \\
4.75\end{array}\right\}$ & 4.80 & 0.8 & $\begin{array}{l}2.80 \\
2.85 \\
2.85\end{array}$ & 2.83 & 0.9 \\
\hline Schulze 原 & $\begin{array}{l}6.35 \\
6.15\end{array}$ & 6.25 & $(1.6)$ & $\begin{array}{l}3.45 \\
3.75\end{array}$ & 3.60 & $(4.6)$ \\
\hline$\frac{(\text { 新法檤一原法值) }}{\text { 新法 值 }} \times 100$ & & 28 & & & 27 & \\
\hline
\end{tabular}

備考 I 監化物を多量に含尧小槽刀溜水。

II 浬田川川口の水。

* ウインクラー單位 $=\operatorname{cc} N / 100 \mathrm{KMnO}_{4} / 100 c c$ 供試水. 
定星條件: Schulze 原法……10cc Sample + 0.5cc1.1 N NaOH + 1cc N/10 $\mathrm{KMnO}_{4}$

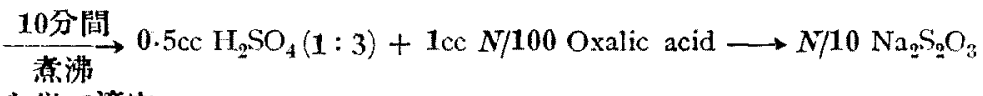
老以て激定.

總 括

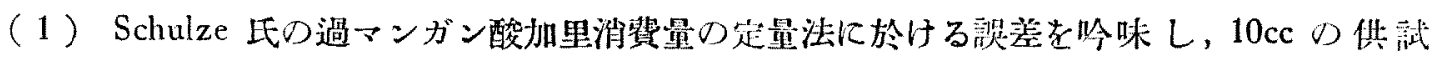
水を使朋する新改良徽量法を栲案した。

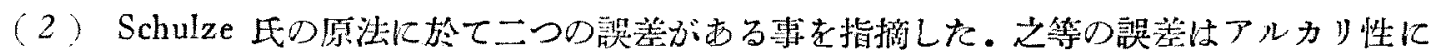
て酸化分解した液を酸性に變する操作に於て短時間內に起るもので其一は有機物に原因し其二

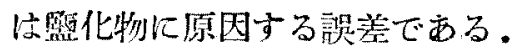

(3) アルカリ性 $\mathrm{KMnO}_{4}$ にて热沸分解した液の $\mathrm{KMnO}_{4}$ の酸化作用を停比するには潒め 酸性にする事なく分解液に直ちに沃化加里を加人る方法が最良でする。

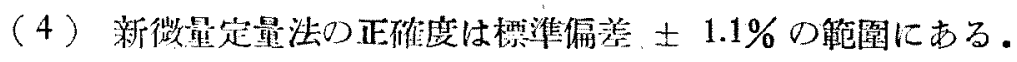

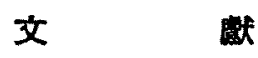

(1) Standard Methods for the Examinatian of Water and Sewage, 8th Ed., publ. by the Amer. Publ. Health Assoc.

(2) Benson. H. K., and Hicks, J. F. G. Jr. : Ind, Eng. Chem., Anal. Ed., 3, 30 (1931).

(3) Ohlmüller-Spitta : Untersuchung und Beurteilung des Wassers und Abwassers (1931).

(4) 蛨!哲夫：本婄，13，1023 (1937).

(5) Aukins, W. R. G. : J. Marine Biol. Assuc., 13, 160 (1923).

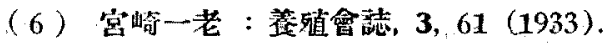

(7) Kleine Mitteilungen für die Mitglieder des Vereins für Wasser-, Ioden- und Lufthygiene, 8 Jahrgang Nr 1/6 (1932).

(8) Sutton : A Systematic Handbook of Volumetric Analysis, 11 th Ed, P. 137.

(9) Winkler, L. W. : Z. anal. Chem., 53, 561 (1914). 